\title{
Siamese quadruplets
}

Several threads run together - and at times get tangled up - in this issue:

- First, the question of whether English can, should, or will become - or indeed whether it already is - the first language of the European Union. Pieter Loonen, a teacher trainer in the Netherlands, and Ross Smith, a British interpreter working in Spain, address this issue in two panoramic articles: the first historical, the second concerned with tendencies and policies that are in their way every bit as crucial as European Monetary Union.

- Second, the de facto success (if that is the word) of English as the lingua franca of international commerce, a state of affairs that embraces everything from the smooth and glossy 'Business English' course materials currently being turned out by ELT publishers to the haphazard - and at times desperate - business of doing deals in a tongue that isn't quite safe for either side. Irreverent and unrelenting, Barry Newman of The Wall Street Journal describes what really goes on when Japanese and Czechs have production lines to maintain and Danes and Egyptians do deals without an Anglophone in earshot.

- Third, the plethora of lexicographical material now available for 'advanced foreign learners', particularly the four similar-butdifferent learners' dictionaries displayed as Siamese quadruplets on our cover. Three new editions of already existing works (Oxford, Longman, and Collins) came out last year, along with a newcomer on the block (Cambridge). Robert Allen in Scotland as a lexicographer and Paul Pauwels in Belgium as a teacher trainer examine them in turn and in detail, each from his special perspective. Such a distinctive tradition - which began in the 1930s in Japan, when Hornby, Gatenby and Wakefield worked on what years later became The Oxford Advanced Learner's Dictionary deserves careful assessment, especially because the stakes are so high and the competition so fierce in this particular global business.

So far, however, the lexical competition has been intranational, British publishers having always had the field to themselves. At some stage, however, the sleeping American giants must surely wake up and seek their share of an apparently insatiable market. There's no business like English business.

\section{Tom McArthur}

The editorial policy of English Today is to provide a focus or forum for all sorts of news and opinion from around the world. The points of view of individual writers are as a consequence their own, and do not reflect the opinion of the editorial board. In addition, wherever feasible, ET generally leaves unchanged the orthography (normally British or American) and the usage of individual contributors, although the editorial style of the journal itself is that of Cambridge University Press.
(C) Cambridge University Press 1996. No contents may be reproduced by any means without the permission of Cambridge University Press.

English Today (ISSN 0266-0784) is a quarterly.

Publisher: Cambridge University Press, Edinburgh Building,

Shaftesbury Road, Cambridge CB2 2RU. Telephone (01223) 312393

Email: English_Today@cup.cam.ac.uk Subscriptions: the current annual subscription price for four issues for libraries and institutions is $£ 51$ outside North America; £26 for individuals; $£ 20$ for students and the retired; airmail £11 per year extra. Apply to Jane Crossland at the above address.

Advertising Sales: write to the Advertising Promoter at the above address.

USA, CANADA AND MEXICO:

Publisher: Cambridge University Press, 40 West 20th Street, New York, NY 10011-4211. Telephone (212) 9243900.

Subscriptions: the current annual subscription price in USA, Canada and Mexico for libraries and institutions is $\$ 81 ; \$ 41$ for individuals; $\$ 29$ for students and the retired. Copies are air-freighted to New York to arrive with minimum delay. Apply to Joseph D. Hranek at the above address.

Advertising Sales: write to the Advertising Coordinator at the above address.

Second class postage paid at New York, $N Y$ and at additional mailing offices.

POSTMASTER: send address changes in USA, Canada and Mexico to English Today,

Cambridge University Press, 110 Midland Avenue, Port Chester, New York, NY 10573-4930.

Japanese prices for institutions (including ASP delivery) are available from Kinokuniya Company Ltd, P.O. Box 55, Chitose, Tokyo 156, Japan.

Letters to the Editor: write to $\mathrm{Dr}$ Tom McArthur, Editor, English Today, 22-23 Ventress Farm Court, Cherry Hinton Road, Cambridge CB1 4HD, UK. Tel 01223245934 , Fax 01223241161

Information on English Today and all other Cambridge journals is available from Cambridge, UK, on http://www.cam.ac.uk/ and from Cambridge New York on http://www.cup.org/.

Printed in Great Britain at the University Press, Cambridge 